communication]. Media Linguistics, $6 \quad$ (2), 164-179. DOI: $10.21638 /$ spbu22.2019.202

У ДК 8137

https://doi.org/10.25076/vpl.41.06

Е.П. Мурашова

Московский государственный лингвистический университет

\title{
ДИНАМИКА СЕМАНТИЧЕСКИХ ИЗМЕНЕНИЙ ТЕРМИНА «НОСТАЛЬГИЯ» КАК КЛЮЧЕВОГО КОМПОНЕНТА PETPO
}

Статья посвящена изучению динамики семантических изменений, которым подвергся термин «ностальгия» со времени своего появления в XVII в. до настоящего времени. На фоне проиессов глобализаџии и информатизаџии общества большую популярность приобретает феномен ретро, имеющий иелью вызвать у реципиента ностальгию. Лингвистического обоснования целесообразности того или иного определения ностальгии при разработке проблем ретро в гуманитарных науках, в том числе в лингвистике, до настоящего времени не представлено. Цель данной статьи - описать изменения, которые были привнесены в семантику термина «ностальгия» с XVII по XXI вв. с учетом его денотативного и коннотативного значений. Материалом исследования служат тексты Британского, Американского и Русского национальных корпусов, опубликованные в период с 1800 по 2020 гг. В результате анализа материала выявлен существенный сдвиг в значении термина «ностальгия». Во-первых, с течением времени было утрачено исходное медицинское значение «тоска по родине как заболевание», и термин стал обозначать тоску не только по месту, но и по времени. Во-вторых, в 1980-х г2. термин «ностальгия» утерял отрицательную коннотацию и приобрел положительную окраску. B-третьих, в XXI в. ввиду постмодернистской тенденции $к$ номадизму, предполагающей сглаживание культурных грании, значение термина «ностальгия» было размыто, что в некоторых случаях преобразовало его в широкозначное существительное. В рамках статьи предлагается 
определение ностальгии, приемлемое для изучения ретро в гуманитарных науках.

Ключевье слова: ностальгия, ретро, языковой корпус, широкозначная лексика, номадизм

\section{UDC 81 37 \\ https://doi.org/10.25076/vpl.41.06 \\ E.P. Murashova \\ Moscow State Linguistic University \\ THE DYNAMICS OF THE SEMANTIC CHANGES OF THE TERM "NOSTALGIA" AS A KEY COMPONENT OF RETRO}

The article is devoted to the dynamics of semantic changes that the term "nostalgia" has undergone over time. Due to globalization and informatization the phenomenon of retro is gaining popularity, its aim being to evoke nostalgia. There has still been no linguistic justification of the definition of nostalgia when studying retro in humanitarian sciences. The aim of the present paper is to describe changes introduced to the semantics of the term "nostalgia" since its appearance in the XVII c. till nowadays, including its denotative and connotative meanings. The material of the research is texts from the British, American and Russian national corpora published from 1800 to 2020. The analysis yielded a significant shift in the meaning of the term "nostalgia". First, the term lost its original meaning of "disease" and came to denote a yearning not only for a place, but also time. Second, in the 1980s the term "nostalgia" lost its negative connotation and acquired a positive one. Third, in the XXI c. owing to the postmodern tendency towards nomadism the meaning of "nostalgia" was blurred and partially desemanticized. In the article a definition of "nostalgia" is suggested that can be used when studying retro in the humanities.

Keywords: nostalgia, retro, language corpus, vocabulary with a broad meaning, nomadism

\section{Introduction}

At present there is a great surge of interest in the past, taking place against the background of ongoing worldwide informatization and 
digitalization. In various spheres of life like marketing, art, fashion, music, literature and others, the so-called retro style is gaining immense popularity.

Retro is most often defined as reproduction of objects, tendencies and motifs of bygone days with the aim of evoking a recipient's pleasant memories and positive past-related associations. In applied disciplines such as marketing or design, retro, as a rule, aims to persuade the target audience to do something, e.g. to buy a product, participate in an activity, vote for a certain candidate in an election, etc.

It is largely believed that retro is only effective when it serves as a memory trigger and evokes the emotion of nostalgia, or a strong longing for the past, hence nostalgia could be a measure of the effectiveness of retro. Though nostalgia is considered a key feature of retro and as such has been studied a lot in humanitarian sciences like anthropology, psychology, philosophy, sociology, marketing, journalism and cultural studies (Angé \& Berliner, 2020; Batcho, Shikh, 2016; Baudrillard, 1994; Boym, 2001; Cervellon \& Brown, 2018; Davis, 1979; Harper, 1966; Jacobsen, 2020; Niemeyer, 2014; Reynolds, 2011; Routledge, 2016; Sierra \& McQuitty, 2007; Wilson, 2014), the semantics of the term "nostalgia", especially its diachronic dimension, remains understudied.

The research in question aims to reveal and describe the changes the term "nostalgia" has undergone through time since its first appearance in the XVII c. till nowadays. We proceed from the assumption that today's understanding of "nostalgia" differs a lot from the original one both in denotative and connotative meaning.

To achieve the aim of the research a number of questions are to be answered:

1) Is nostalgia a yearning for a place or time?

2) Is nostalgia a positive or a negative emotion?

3) Is nostalgia collective or individual?

4) Is nostalgia triggered by a real experience or is it solely a product of our imagination?

5) What is the most accurate definition of "nostalgia" for research into retro in humanitarian sciences, including linguistics?

The practical value of the study consists in facilitating the right choice of communicative strategies by marketing, PR, journalism, arts and design practitioners. A better understanding of nostalgia could form 
the basis of an effective retro-oriented marketing mix, thereby ensuring a company's competitive advantage.

\section{Material and methods}

The material for the present study is an extensive body of Englishand Russian-language texts from the British National Corpus (BNC), the Corpus of Contemporary American English (COCA) and the Russian National Corpus (RNC) published in the period from 1800 to 2020. The examples of the use of the term "nostalgia" have been retrieved from the general corpus and subject to statistical, comparative, definitional and contextual analysis. The material in Russian was translated by us.

The research was done in two stages. First, an overview of the history of the term "nostalgia" was given. Second, corpus data containing the term "nostalgia"/ «ностальгия» were selected and analyzed from the point of view of frequency of occurrence and lexical combinability. We selected lexemes in any form related to "nostalgia"/ «ностальгия» and then applied to them the search criterion of "positive/negative connotation" to find out if the context of use was positive or negative.

In the paper in question we only included the material published as early as the XIX c. till nowadays, as before the given period the interpretation of "nostalgia" had not changed. There was no limitation as to the source, topic, type of discourse or genre of the material. We also did not aim to compare the use of the term in different languages and across different cultures, though it could be a promising topic for further research.

\section{Results and discussion}

The term "nostalgia" was first coined by the Swiss medical student Johannes Hofer in his doctoral thesis, defended in 1688. As the form suggests, the original meaning of "nostalgia" (from Greek nostos "homecoming" and algos "pain") is "homesickness". Initially, the term referred to the severe homesickness of Swiss mercenaries who had to leave the Swiss Alps for the European plains to perform their military duty. J. Hofer described the numerous physical and psychological symptoms of nostalgia that included melancholy, weakness, insomnia, anorexia, etc.

Doctors believed the illness was curable and its symptoms could be treated with medicine, leeches or a return back home. The 
understanding of nostalgia as a medical condition associated with separation from home continued well into the XIX c (Routledge, 2016, p. 4).

As for the connotation, at first nostalgia had a negative colouring. The disease was not centred in any part of the body and was largely neurological, which made it difficult to prevent, diagnose and treat the symptoms. Closer to the end of the XIX c. Charles Darwin pointed out the positive effects of nostalgia when writing about emotions triggered by recollection of the past: "The feelings which are called tender are difficult to analyse; they seem to be compounded of affection, joy, and especially of sympathy. These feelings are in themselves of a pleasurable nature, excepting when pity is too deep, or horror is aroused <..." (Darwin, 1873, p. 216).

Being interested in the development of the term, first, we counted the frequency of its occurrence in the three corpora and checked if the earliest mentions of "nostalgia" differed from its original meaning of a negative medical condition.

The analysis of the frequency of the lexeme "nostalgia" and its related forms yielded the following results:

BNC -475 entries, the earliest use found in 1989;

COCA - 4768 entries, the earliest use found in 1990;

$\mathrm{RNC}-1254$ entries, the earliest use found in 1850.

Once again it is necessary to stress that we did not make any attempt to compare the use of the term in British English, American English and Russian.

The earliest mentions of "nostalgia" (the XIX c.) were registered in the Russian corpus and each of them contains the semes of the original meaning of nostalgia, i.e. "psychological disease", "homesickness" and "negative feeling". It is noteworthy that sometimes the definition of nostalgia is given in parenthesis (3), which goes to show the term still needed to be explained. The notion of "home" is extended to include "homeland", "family" or "friends" (1), (2), (3). In most cases the meaning of "psychological disease" is supplemented by indications of "physical disease" (2), (4), (5). E.g.:

(1) Отчего нашла на меня именно сегодня эта ностальгия по отечеству? [П.И. Чайковский. Письма Н. Ф. фон-Мекк (1879)]

(«Why am I overwhelmed on this very day by this nostalgia for my homeland? [P.I. Tchaikovsky. Letters to N.F. Von Meck (1879)]»- 
E.M.)

(2) Я выздоровела, медленно поправляясь, $и$, быть может от слабости, впала в ностальгию, - я только и думала о моей семье, о свидании с нею... [Н.А. Тучкова-Огарева. Воспоминания (1890)]

(«I got well, recovering slowly, and maybe owing to my weakness I lapsed into nostalgia. I only thought about my family and meeting them... 「N.A. Tuchkova-Ogareva. Memoirs (1890)]»-E.M.)

(3) Овладевая душою Глинки все более и более, оно наконеи приняло совершенный характер душевного недуга, известного под названием «ностальгии» (тоски по родине). [С.А. Базунов. Михаил Глинка. Его жизнь и музыкальная деятельность (1892)]

(«Overwhelming Glinka's soul more and more, it finally took the form of a perfect mental ailment, known as "nostalgia" (a yearning for the homeland). [S.A. Bazunov. Mikhail Glinka. His Life and Musical Activity (1892)»-E.M.)

(4) Не смотря на все удобства жизни в доме Казакевича, я начал физически слабеть во мне развилось чувство необъяснимой тоски и меланхолия, а за тем ностальгия. [Б.К. Кукель. Из эпохи присоединения Приамурского края // «Исторический вестник», 1896] (The original text is reproduced unchanged. - E.M.)

(«Despite all the conveniences of life in Kazakevich's house, I began to feel physically weak, I developed the feeling of an inexplicable yearning and melancholy, then nostalgia followed. [B.K. Kukel. From the Era of Accession of the Amur Region // "Historical Herald", 1896]»- E.M.)

(5) На море было постоянное волнение, и я, как новичок, сильно страдал от морской болезни, да к тому же, не видя долго берега, стал ощущать тоску, которая была последствием перенесенной мною в течение зимы ностальгии. [Б.К. Кукель. Из эпохи присоединения Приамурского края // «Исторический вестник», 1896]

(«The sea was constantly rough, and I as a novice suffered greatly from seasickness, moreover, not seeing the shore for a long time, I began to feel a yearning which was an effect of the nostalgia I had been ill with in the winter. [B.K. Kukel. From the Era of Accession of the Amur Region // "Historical Herald", 1896]»- E.M.)

As we can judge by the previous examples, the main meaning of 
nostalgia in the XIX c. was "a longing for a place", to be specific, for the homeland.

Since 1974 there have been more and more instances of the use of nostalgia in the meaning of "a longing for the past time".

Устали и поняли, что это всего лишь бессильная ностальгия по невозвратимому прошлому. [А.С. Черняев. Дневник (1974)] (RNC)

(«They got tired and realized it was merely a helpless nostalgia for the non-returnable past. [A.S. Chernyaev. Diary (1974)] »- E.M.)

In the 1990s "nostalgia" came to be frequently used with particular time indicators like adverbial modifiers of time, numbers, precedent names and precedent situations typical of a certain era. The following example illustrates the use of time-related vocabulary, a date and a precedent name. All these means intend to evoke images of the past that must be familiar to the recipient:

This mother-daughter comedy has all the trappings of 1963 nostalgia -- the pop tunes, the cars and clothes, the Kennedy assassination -- plus another movie anachronism: a lot of oldfashioned heart. ("Critics' Voices". MAG: TIME, 1991) (COCA)

За всем этим - ностальгия по мифической царской России с высоким культурным сообществом <... [С. Г. Кара-Мурза. «Совок» вспоминает свою жизнь (1998)] (RNC)

(«Behind all this there is nostalgia for the mythical tsarist Russia with an elite cultural community < ..> [S. G. Kara-Murza. "'Sovok" Remembers His Life» (1998)] »- E.M.)

Since 1981 "nostalgia" has been used in a positive meaning, though it is still occasionally called a disease:

Ах, ностальгия - прекрасная болезнь, от которой невозможно и не нужно лечиться. [Леонид Утесов. «Спасибо, сердце!» (1982)] (RNC)

(«Ah, nostalgia is a beautiful illness that one can't and needn't cure» [Leonid Utesov. “Thanks, Heart!” (1982)]»-E.M.)

The word "fit" (Russ. - «приступ») is often used in combination with "nostalgia" to denote both, a strong physical reaction and a strong emotion, which means that nostalgia like an illness is intense enough to produce visible physical effects:

У него случилось что-то вроде приступа ностальгии. [Аркадий Стругацкий, Борис Стругацкий. Град обреченный 
(1972)] (RNC)

( $\ll \mathrm{He}$ had some kind of a fit of nostalgia. [Arkady Strugatsky, Boris Strugatsky. The Doomed City (1972)] »-E.M.)

$<\ldots>$ a son she named Miguel in a fit of nostalgia for her firstborn. (Arturo Islas «FIC: Migrant Souls», 1990) (COCA)

One can't but notice the numerous positively coloured adjectives, nouns and verbs used with the lexeme "nostalgia" in all the three corpora. There seems to be a dramatic rise in the number of examples of positively-coloured instances of the use in the 1990s.

RNC: предавались ностальгии/ предаваться ностальгии («to indulge in nostalgia» - Е.М.) (1982, 1991-1994); ностальгия по старым, хорошим, людским отношениям («nostalgia for good old human relationships» - E.M.) (1987-1998); с нежностью $и$ ностальгией («with tenderness and nostalgia»- E.M.) (1999).

BNC: It was a magical evening of pure nostalgia enjoyed by an audience from nine to 90 years of age. (1985-1994); a mixture of fondness and nostalgia (1990); to indulge in the sheer nostalgia of days bygone (1991).

COCA: a fond nostalgia (1990); nostalgia for an idyllic past (1992); the magic of nostalgia (1995); A warm flood of nostalgia suffused him (1996).

The frequent use of positively coloured epithets deserves special mention:

RNC: талантливая ностальгия («talented nostalgia»- E.M.) (1981); Взволнованный столь трогательной формой ностальгии («Worried by such a touching form of nostalgia» - E.M.) (1982); сентиментальной ностальгии («sentimental nostalgia» - E.M.) (1991-1994); с мармеладной ностальгией вспоминаю <...> («I remember with marmalade nostalgia $\langle\ldots>$ » - E.M.) (1997); атмосферу рафинированной, хрупкой ностальгии по чему-то («the atmosphere of a refined, fragile nostalgia for something» - E.M.) (1998).

BNC: a mood of relaxed and optimistic nostalgia (1984); softheaded nostalgia (1985-1994); with affectionate nostalgia (1991); the honeyed glow of nostalgia (1993); a romantic and utopian nostalgia (1994).

COCA: the warm nostalgia of those holidays (1990); romantic nostalgia (1991); a real honest-to-goodness nostalgia boom (1992); 60s 
feel-good nostalgia (1993); Golden-Years nostalgia (1995).

The most frequently used word combination with "nostalgia" in all the three corpora seems to be "nostalgia for the good old days" (Russ. «ностальгия по старым добрым временам») (at least 1 occurrence per 100 entries), which illustrates the semes of "time" and "positivity" in the meaning of the word.

As for the perception of nostalgia as a collective or individual emotion, it becomes clear that it can be both, but most frequently a reference is made to something in collective memory.

In the RNC there are numerous mentions of the nationality word "Russian" together with "nostalgia" or abundant use of "nostalgia" in combination with the different forms of the first-person plural personal pronoun, which goes to show that to the Russians nostalgia is a largely collective emotion:

А тоска, а русская, присущая только нам в сильной мере, непомерной мере - ностальгия! [Т.В. Доронина. Дневник актрисы (1984)] (RNC)

(«But a yearning, a Russian yearning, only characteristic of us in a strong form - nostalgia! [T.V. Doronina. Diary of an Actress (1984)] » - E.M.)

The use of the cultural symbols of Russia is also worth mentioning, e.g. in the following abstracts a reference is made to the Russian birch tree, the Russian traditional dish called "Siberian dumplings" and the landmarks of the typical Russian scenery:

$<\ldots>$ но ведь ностальгия - это что-то вроде березок, пельменей по-сибирски, маковок церквей на Пятницкой, заснеженных полей или желтого клена над могилой моего отца на Введенском кладбище в Москве. [Михаил Козаков. Актерская книга (1978-1995)] (RNC) («<... but nostalgia is something like birch trees, Siberian dumplings, the domes of small churches in Pyatniskaya, snow-covered fields or the yellow maple above my father's grave at Vvedenskoye Cemetery in Moscow [Mikhail Kozakov. Acting Book (1978-1995)] »- E.M.)

Шукшин в состоянии ностальгии обычно ходил целовать березки - русские в Париже идут кушать блинчики за 200 франков. [Игорь Мартынов. Париж - город контрастов // «Столица», 1997.06.10] (RNC)

(«Shukshin in the state of nostalgia usually went to kiss birch trees - 
Russians in Paris go to eat pancakes for 200 francs [Igor Martynov. Paris: A City of Contrasts // "Capital”, 1997.06.10] »- E.M.)

As compared to the RNC, the BNC and the COCA do not seem to include many examples of "British/American nostalgia". But we believe that it does not necessarily mean that nostalgia is only individual in English-speaking countries. It is also collective, but its "collectivism" is expressed in other ways, e.g. through references to some phenomena known to each target individual. The fact that a cultural phenomenon is well-known to all representatives of the target audience is illustrated by the absence of any explanations in the text, thus, the addresser relies on collective memory (Sibul, 2017). To decode the following message correctly, the recipient has to have some cultural background, especially knowledge of precedent names:

Best riot for teenagers: John Doyle's Sixties nostalgia version of The Sleeping Beauty, with arm-waving singalong and fast-forward time-travelling, at the Liverpool Everyman. [[Guardian, elect. edn. of 19891221]. London: Guardian Newspapers Ltd, 1989, Arts material, pp. ??. 921 s-units.] (BNC)

Nostalgia also gets a clear-cut individual "dimension", e.g. a person can experience nostalgia for a period in their life (more often childhood or youth):

It had been an uncomfortable and disturbing sensation and he was still wondering whether it hadn't been only the incense, the spring evening, and nostalgia for his boyhood. ("An unsuitable attachment". Pym, Barbara. London: Pan Macmillan Pubs, 1993, pp. 13-154. 2519 sunits.) (BNC)

In case nostalgia is individual, there is often a mention of a person's individual reminiscences of past experiences, especially related to their childhood, career or food:

Я испытывваю настоящую ностальгию... хочу домой, хочу к Маме, хочу к детям, хочу ходить по своей квартире, хочу лежать в своей постели, не могу понять, как в ней может лежать на Маминых свадебных простынях кто-то другой, хочу музыку, хочу ливень, хочу слушать сказки, хочу бегать босиком по лужам <... . [Татьяна Окуневская. Татьянин день (1998)] (RNC)

( «I feel a real nostalgia... I want to go home, I want to go to Mum, to the children, to walk around my flat, to lie in my bed, I can't 
understand how somebody else could lie on Mum's wedding sheets, I want music, I want pouring rain, I want to listen to fairy tales, stomp barefoot in puddles <... [Tatyana Okunevskaya. Tatyana's Day (1998)]»-E.M.)

At the height of his fame and glory he thinks with nostalgia of the rough country food of his childhood. ("An omelette and a glass of wine". David, Elizabeth. London: Penguin Group, 1987, pp. 156-274. 1944 s-units.) (BNC)

Since the 2000s there has been no significant observable change in the understanding of "nostalgia" - it is still treated as a positive emotion and still refers to the past time rather than a past place, but the entries in the RNC are mainly limited to reminiscences of the Soviet times and in the BNC and the COCA reminiscences tend to include periods from the $60 \mathrm{~s}$ to the $90 \mathrm{~s}$. Thus, nostalgia has been narrowed down to the time of a society's immediate past that are in the living memory of its members, e.g.:

Китайские космическая и атомная корпораџии также вызыьвали скорее ностальгию по советскому прошлому, чем восхищение последним словом техники. [Евгений Огородников. Поднимется ли с колен «Уралмаш»? // «Эксперт», 2015] (RNC)

(«The Chinese space and atomic energy corporations also caused nostalgia for the Soviet past rather than admiration for state-of-the-art technology. [Evgeny Ogorodnikov. Will "Uralmash" Get Off Its Knees? // “Expert”, 2015] 》- E.M.)

The 1980s nostalgia is finally paying off! ("Thank God, Someone Is Making a Documentary About Jackie Collins", MAG: Jezebel, 2019) (COCA)

There are more examples (as compared to the previous periods) demonstrating that the meaning of nostalgia has broadened to refer not only to a specific period of time but also to the pre-digital age when life used to be closer to a human's biological self. Thus, nostalgia came to denote the real and authentic as opposed to the virtual and fake, e.g.:

One of the great sad lessons that, among the many diminishing returns of technology that we've learned over the last hundred years, is that the virtual really isn't an adequate substitute for the authentic. All that we've lost is just such a theme. And we see that in all the nostalgia stuff; there is an awareness on some level that's very widespread, that we've just lost so much. We're just cut off. As life 
becomes more and more artificial and mediated and disembodied, and the techno culture it's just becoming very impoverished and cold and empty and perhaps it just is. ("Yu Koyo Peys", 2006) (COCA)

Moreover, the meaning of nostalgia seems to have blurred so as to include not only the past but also the present and even the future:

I have nostalgia for something. It just hasn't happened yet. But it's gonna happen $<$... > ("Women in Trouble", 2009) (COCA)

In some cases, it becomes clear that nostalgia can occasionally be treated as a "shell noun". The term "shell noun" was introduced by Hans-Jörg Schmid in 1997 to denote a class of abstract nouns that only get their meaning in context (Schmid, 2000). Like vague category markers, "shell nouns" help to deliberately de-focus some information and create "ad hoc, instantial categories relevant to the needs of the present discourse" (Malyuga, McCarthy, 2018, p. 40). For example, in the following abstract the word is used in the meaning of "expectations":

Perhaps it's too much to expect a remake to live up to our nostalgia.

(«'Shadow of the Colossus' remake is missing something vital», MAG: Engadget, 2018) (COCA)

The meaning of "nostalgia" is now so broad that it has become possible to be "nostalgic for nostalgia", which should probably be interpreted as "wanting to bring back something from the past":

Colt hired this band and when he did he just kept screaming "it's gonna be 1998 all over again! " Poor guy, he's just, he's nostalgic for nostalgia. ("The Wedding Party", 2016) (COCA)

Having analyzed the evolution of the term, let us move on to the way it is handled in today's study of retro. Most definitions of nostalgia, as can be expected, revolve around its ability to conjure up images of the past and its positive connotation.

One of the most cited definitions of nostalgia was given by F. Davis: "A positively toned evocation of a lived past in the context of some negative feeling toward the present or impending circumstances" (Davis, 1979, p. 18). A similar definition was given by J.J. Sierra and S. McQuitty: "A yearning for the past, or a fondness for tangible or intangible possessions and activities linked with the past, and is experienced when individuals feel separated from an era to which they are attached" (Sierra, McQuitty, 2007, p. 99). Both of the definitions 
bring out discontent with the present as the main reason for the appearance of nostalgia.

Other definitions include a broader understanding of nostalgia and bring out its contradictory nature. One of the earliest definitions demonstrating that nostalgia is woven of paradoxes was suggested by theologian and philosopher R. Harper in 1966:

"Nostalgia combines bitterness and sweetness, the lost and the found, the far and near, the new and the familiar, absence and presence. The past which is over and gone, from which we have been or are being removed, by some magic becomes present again for a short while. But its realness seems even more familiar, because renewed, than it ever was, more enchanting and more lovely" (Harper, 1966, p. 120).

More recent definitions of nostalgia, like the abovementioned one, are broad and highlight its inherent paradoxicality, e.g. "a bittersweet longing for former times and spaces $<\ldots>$ private or public return to the past, and sometimes to an interlinking imagination of the future" (Niemeyer, 2014, p. 1).

The ambivalence of nostalgia appears to consist in the following features:

1) "bittersweetness";

2) oldness and novelty;

3) the ability to evoke images of the past, the present and the future;

4) realness and unrealness.

Strictly speaking, nostalgia is not one emotion, but rather a combination of several polar opposite emotions, both positive and negative, hence its "bittersweetness".

It is also stated that nostalgia is not always based on a person's real experiences: it could include fantasies and assumptions or images that a person has not encountered themselves but is aware of because they possess the so-called collective memory. Nostalgia brings together knowledge about the past and the present and ideas about the future.

It is of interest that in psychology different forms of nostalgia are described. One of them is the so-called "anticipatory nostalgia" "missing aspects of the present before they are lost in the future" (Batcho, Shikh, 2016, p. 75). Anticipatory nostalgia is opposed to personal nostalgia that looks back on the past. Unlike anticipatory nostalgia, personal nostalgia tends to be positive rather than negative.

The new perception of nostalgia as a yearning for the present can be 
illustrated with the help of the recent language material of the end of the XX c. - the XXI c. In the following film description, we find the word combination "nostalgia for the present" which used to be perceived as an oxymoron back in the mid-1990s:

<... > ONE OF THE CHARACTERISTICS OF "MANHATTAN" IS THAT IT CREATES A NOSTALGIA FOR THE PRESENT. (The font of the original text is unchanged. - E.M.) ("Woody Allen: A Documentary", 2012) (COCA)

Moreover, the definitions make it clear that nostalgia can be both, individual and collective. Inasmuch as nostalgia pertains to the domain of the collective, it is possible to treat it as a component of retro.

Retro is a complex object of research that can't be defined in one single way because it is understood differently depending on the field of knowledge. Retro is mostly studied in the humanities where it is treated as a multifaceted phenomenon of culture that can influence human mind and behaviour.

In linguistics retro is researched insufficiently and no single linguistic definition of retro has been worked out and justified. In our opinion, when trying to define retro it is necessary to bear in mind the reason for the popularity of retro. Retro must have emerged as a response to the postmodern challenges of the ongoing processes of informatization and digitalization which are believed to have put pressure on a human's psychology. On the one hand, technology has greatly simplified our life enabling quick transportation, transmission of information and communication, but, on the other hand, it has made it more complicated in that we feel cut off from nature and lost in the technosphere. The acute conflict between a human as a biological creature ("natura naturata") and a human as a creator ("natura naturans") makes us turn to the past in search of simplicity and authenticity, hence the demand for old or old-fashioned artefacts, traditional means and forms of communication.

However, it is not simple to resolve the conflict by simply remembering the past because, as J. Baudrillard puts it, the main referential for reconstructing the past, i.e. history, has been lost and has become a "retro scenario" (Baudrillard, 1994). Feeling nostalgia for a lost referential, people have to create artificial substitutes called "simulacra" with the help of the code of their culture. Retro proves to be one of such simulacra: it manifests an attempt to resurrect history 
through simulation or rather to create a new history based on knowledge of the past.

Being a man-made product, retro is largely a phenomenon of culture capable of storing and imparting cultural knowledge. Nostalgia can be considered a key component of retro as retro is initially triggered by nostalgia for the past and the latter, in its turn, is triggered by retro. It is worth mentioning that retro mainly manifests itself through mass culture, or pop culture (as opposed to the so-called high culture), because, just like real history, a "retro scenario" has to be created by the masses. At the same time the role of an individual can't be underestimated. While pondering on the connection between nostalgia and retro, music journalist and author S. Reynolds points out that "the intersection between mass culture and personal memory is the zone that spawned retro" (Reynolds, 2011).

To our mind, retro in linguistics is to be defined as a linguo-cultural concept that imparts knowledge about the past, the present and the future with the aim of evoking nostalgia.

Having analyzed the development of the term "nostalgia", we suppose that when studying retro researchers have to proceed from the idea that the key emotion of retro, that is nostalgia, has evolved over time from a term denoting "a disease" through "a positive emotion caused by images of the past" to a broader one dealing with the past, the present and the future, the individual and the collective. It has undergone a shift in meaning and semantic blurring and, as has been demonstrated above, occasionally can be treated as a "shell noun".

The complex process of the transformation of the meaning of "nostalgia" falls under the general cultural trend of nomadism that appeared as a reaction to the challenges of postmodernism and has recently become an interdisciplinary subject widely discussed in humanitarian sciences. Nomadism is one of the popular concepts of postmodern philosophy that refers to the extreme mobility and deterritorization of culture. One of the most well-known interpretations of the nature of nomadism was suggested by the French philosophers G. Deleuze and F. Guattari, the founders of the so-called "nomadology" project (Deleuze, Guattari, 1986). They believe that nomadism is a strategy used to challenge and fight the rigidity and strictness imposed by the state, hence the methods "nomads" typically resort to smoothing spaces, blurring borders and changing places. 
Though nomadism is usually associated with travelling, it is not limited to the category of "place". Nomadism could also manifest itself in the way of thinking - the "nomad thinking": " $<\ldots>$ one should be able to think without borders, without limitations. Nomadism frees our thought, not simply in the sense that we can think whatever we want, but more so in that we can think in whatever way we want" (Kuperus, 2016). Nomad thinking involves travelling through space as well as time. The same can be said about nostalgia: it encapsulates all forms of displacement in that it helps to travel across time and space in one's imagination. So, both nomadism and nostalgia break borders, enabling a person to think critically and broaden their mind.

Nomadism can be successfully used to explain the nature of many postmodern concepts including nostalgia and retro, as was demonstrated by I.A. Guseynova in her linguo-culturological study of retro (Guseynova, 2017).

Thus, we suggest that in retro-focused research nostalgia should be understood broadly as a positive emotion intentionally evoked by the real or imagined images of the past, the present and the future, pertaining to individual or collective knowledge, experiences and/or memory. It should be highlighted that, to our mind, nostalgia is conjured up intentionally with the help of retro means and, paradoxically, does not necessarily address a recipient's memory, but rather involves cultural background knowledge or personal experiences gained through interaction with culture.

\section{Conclusion}

The conducted research shows that the term "nostalgia" has undergone a significant semantic shift since it was coined in the XVII c. to denote the disease of extreme homesickness. The changes in the meaning of the term are the following ones.

First, the term was demedicalized and since the 1970s has been used to denote not only a yearning for the past place, but also for the past time.

Second, in the 1980s "nostalgia" began to lose its negative connotation and acquired a positive colouring. It came to be treated as a sought-for condition.

Third, nostalgia does not necessarily belong to the realm of the individual. It could be both, individual and collective in that it appeals to both, personal knowledge, experiences and/or memory and collective 
memory.

Fourth, as the term addresses the collective as well as the individual, one does not necessarily need to have experienced something first hand for nostalgia to be evoked in their mind. Cultural background knowledge could suffice to feel nostalgic for the places you have never been to and the times you have never lived in. Furthermore, nostalgia brings together knowledge of the past and the present and ideas or fantasies about the future, so nostalgia could be largely based on a person's imagination, but not on reality.

Last, it is important to highlight that the term "nostalgia" has the same nature as the phenomenon of retro. Just like retro, nostalgia demonstrates features typical of nomadism, a cultural trend that aims to address the challenges of postmodernism. In the XX c. the meaning of nostalgia was blurred and came to denote things and events of the predigital age. In certain cases, the meaning is so broad that "nostalgia" acquires the status of a "shell noun", which could be used to influence the recipient in a desired way, e.g. conveying either a positive or a negative emotion.

The main changes the term "nostalgia" has undergone over time are to be considered when doing research into retro in the humanities.

\section{Литература}

1. Гусейнова И. А. Роль феномена «ретро» в конструировании современного культурно-исторического пространства (на примере российских современных ретродетективов) // Вестник Московского государственного лингвистического университета. Гуманитарные науки. 2017. Т. 6. № 777. С. 308315.

2. Angé O., Berliner D. Ecological Nostalgias: Memory, Affect and Creativity in Times of Ecological Upheavals. Berghahn Books, 2020.

3. Batcho K.I., Shikh S. Anticipatory nostalgia: Missing the present before it's gone // Personality and Individual Differences. 2016. № 98. Pp. 75-84.

4. Baudrillard J. Simulacra and Simulation. Ann Arbor: University of Michigan Press, 1994.

5. Boym S. The Future of Nostalgia. New York: Basic Books, 2001. 
6. British National Corpus (BNC). URL: https://www.englishcorpora.org/bnc (дата обращения: 02.11.2020)

7. Cervellon M.C., Brown S. Revolutionary Nostalgia: Retromania, Neo-Burlesque, and Consumer Culture. Emerald Publishing Limited, 2018.

8. Corpus of Contemporary American English (COCA). URL: https://www.english-corpora.org/coca (дата обращения: 02.11.2020)

9. Darwin Ch. The Expression of the Emotions in Man and Animals. London: John Murray, Albemarle Street, 1873.

10.Davis F. Yearning for Yesterday: A Sociology of Nostalgia. New York: Free Press, 1979.

11.Deleuze G., Guattari F. Nomadology: The War Machine. 1986.

12.Harper R. Nostalgia: An Existential Exploration of Longing and Fulfillment in the Modern Age. Cleveland: Press of Western Reserve University, 1966.

13.Jacobsen M.H. Nostalgia Now: Cross-Disciplinary Perspectives on the Past in the Present. New York: Routledge, 2020.

14.Kuperus G. Ecopolitical Homelessness: Defining Place in an Unsettled World. New York: Routledge, 2016.

15.Malyuga E., McCarthy M. English and Russian vague category markers in business discourse: linguistic identity aspects // Journal of Pragmatics. 2018. № 135. C. 39-52.

16. Niemeyer K. Yearning for the Past, Present and Future / K. Niemeyer // Introduction: Media and Nostalgia. Houndmills: Palgrave Macmillan, 2014. P. 1-26

17.Reynolds S. Retromania: Pop Culture's Addiction to Its Own Past. New York: Faber and Faber, 2011.

18.Routledge C. Nostalgia: A Psychological Resource. New York: Taylor \& Francis, 2016.

19. Sibul V. Psycholinguistic analysis of lexical-semantic structure in linguistic consciousness of Russian, English and German native speakers // Training, Language and Culture. 2017. №1(2). Pp. 5470. Doi: $10.29366 / 2017$ tlc.1.2.4

\section{References}

Angé, O., \& Berliner, D. (eds.) (2020). Ecological Nostalgias: Memory, Affect and Creativity in Times of Ecological Upheavals. 
Berghahn Books.

Batcho, K.I., \& Shikh, S. (2016). Anticipatory nostalgia: Missing the present before it's gone. Personality and Individual Differences, 98, 75-84.

Baudrillard, J. (1994). Simulacra and Simulation. Ann Arbor: University of Michigan Press.

Boym, S. (2001). The Future of Nostalgia. New York: Basic Books.

British National Corpus (BNC). Retrieved from: https://www.englishcorpora.org/bnc (accessed: 02.11.2020)

Cervellon, M.-C., \& Brown, S. (2018). Revolutionary Nostalgia: Retromania, Neo-Burlesque, and Consumer Culture. Emerald Publishing Limited.

Corpus of Contemporary American English (COCA). Retrieved from: https://www.english-corpora.org/coca (accessed: 02.11.2020)

Darwin, Ch. (1873). The Expression of the Emotions in Man and Animals. London: John Murray, Albemarle Street.

Davis, F. (1979). Yearning for Yesterday: A Sociology of Nostalgia. New York: Free Press.

Deleuze, G. \& Guattari, F. (1986). Nomadology: The War Machine.

Guseynova, I.A. (2017). Rol' fenomena «retro» v konstruirovanii sovremennogo kul'turno-istoricheskogo prostranstva (na primere rossijskih sovremennyh retrodetektivov) [The role of retro in constructing the modern cultural and historical space (an analysis of contemporary retro-detective prose)]. MSLU scientific newsletter. Series "Humanitarian Sciences", 6 (777), 308-315.

Harper, R. (1966). Nostalgia: An Existential Exploration of Longing and Fulfillment in the Modern Age. Cleveland: Press of Western Reserve University.

Jacobsen, M.H. (Ed.). (2020). Nostalgia Now: Cross-Disciplinary Perspectives on the Past in the Present. New York: Routledge.

Kuperus, G. (2016). Ecopolitical Homelessness: Defining Place in an Unsettled World. New York: Routledge.

Malyuga, E., \& McCarthy, M. (2018). English and Russian vague category markers in business discourse: linguistic identity aspects. Journal of Pragmatics, 135, 39-52.

Niemeyer, K. (2014). Introduction: Media and Nostalgia. In Niemeyer, K. (Ed.) Media and Nostalgia: Yearning for the Past, Present and Future, (pp. 1-26). Houndmills: Palgrave Macmillan. 
Reynolds, S. (2011). Retromania: Pop Culture's Addiction to Its Own Past. New York: Faber and Faber, Inc.

Routledge, C. (2016). Nostalgia: A Psychological Resource. New York: Taylor \& Francis.

Russian National Corpus (RNC). Retrieved from: https://ruscorpora.ru/new/en/index.html (accessed: 02.11.2020)

Schmid, H.-J. (2000). English Abstract Nouns as Conceptual Shells: From Corpus to Cognition. Berlin, New York: Mouton de Gruyter.

Sibul, V. (2017). Psycholinguistic analysis of lexical-semantic structure in linguistic consciousness of Russian, English and German native speakers. Training, Language and Culture, 1(2), 54-70. Doi: 10.29366/2017tlc.1.2.4

Sierra, J.J., \& McQuitty, S. (2007). Attitudes and Emotions as Determinants of Nostalgia Purchases: An Application of Social Identity Theory. In Journal of Marketing Theory and Practice, 15(2), 99-112.

Wilson, J.L. (2014). Nostalgia: Sanctuary of Meaning. Minneapolis: University of Minnesota Publishing.

УДК 811.131.1

https://doi.org/10.25076/vpl.41.07

С.Н. Орлова

А.А. Конькова

Российский университет дружбы народов

\section{ЭМОТИВНЫЕ СРЕДСТВА ЯЗЫКА КАК СПОСОБ ВОЗДЕЙСТВИЯ В ИТАЛЬЯНСКОМ И АНГЛИЙСКОМ ПУБЛИЦИСТИЧЕСКОМ ДИСКУРСЕ}

\footnotetext{
В статье через призму сопоставительного анализа рассматриваются особенности эмотивной функиии языка в публицистическом дискурсе, а также демонстрируется, какие средства языка могут быть использованы для воздействия на читателя. Целью данной статьи является выявление коммуникативно-прагматических аспектов эмотивной функции, реализуемой в рамках итальянского $и$ английского публицистического дискурса. Актуальность данного исследования обусловливается широким распространением языкового
} 
воздействия в современном публииистическом дискурсе ввиду усиления воздействия на читателя. Новизна заключается в том, что в настоящее время коммуникативно-прагматический аспект эмотивной функиии недостаточно раскрыт в публицистическом дискурсе, а также отсутствует достаточное количество современных работ и исследований, связанных с лингвистическим анализом итальянских и английских газет. Исследование проводилось на основе анализа экономических статей из наиболее авторитетных газет Италии La Repubblica, Corriere della Sera, La Stampa, the Guardian $u$ the Telegraph. В работе использовался коммуникативно-прагматический подход $u$ дискурс-анализ $c$ использованием качественных и количественных методов обработки данных. Были исследованы контекст употребления эмотивных средств языка, частота их употребления в итальянских и английских статьях и их способность осуществлять воздействие на читателя. Приводятся доводы о том, что рассматриваемые лингвистические единицы имеют сильное воздействие на сознание. Итоги исследования расширяют познания о способах воздействия публицистического дискурса на читателя, а также о национальном своеобразии итальянской и английской газеты. В своих выводах авторы подчеркивают, что воздействующий потенциал дискурса реализуется с помощью экспрессивности языковых средств.

Ключевые слова: публицистический дискурс, журналистика, анализ дискурса, семантика, прагматический подход, коммуникативно-прагматический аспект, эмотивная функиия, эмотивность, итальянская статья, английская статья, эмотивные средства языка.

УДК 811.131.1

https://doi.org/10.25076/vpl.41.07

S.N. Orlova

A.A. Konkova

RUDN University

\author{
EMOTIVE MEANS OF LANGUAGE AS A WAY OF \\ INFLUENCE IN ITALIAN AND ENGLISH PUBLICISTIC \\ DISCOURSE
}


The article examines the features of the emotive function of language in publicistic discourse, and also demonstrates what language means can be used for the author's influence on the reader. The aim of this paper is to identify the communicative and pragmatic aspects of emotive function implemented in the framework of Italian and English publicistic discourse. The relevance of this study is due to the wide spread of linguistic influence in modern publicistic discourse in order to increase impact on the reader. The novelty lies in the fact that at present the communicative and pragmatic aspect of the emotive function is not sufficiently disclosed in publicistic discourse, and one can also observe an insufficient number of works and research related to the linguistic analysis of Italian and English newspapers. The research was carried out on the basis of an analysis of economic articles from the most authoritative Italian and English newspapers La Repubblica, Corriere della Sera and La Stampa, the Guardian and the Telegraph. The research was conducted on the basis of communicative and pragmatic approach and discourse analysis using qualitative and quantitative methods of data processing. The context of the use of emotive language means, the frequency of their use in Italian and English articles and their ability to influence the reader were investigated. Arguments are given that the linguistic units under consideration have a strong effect on consciousness. The results of the study expand knowledge about the ways in which publicistic discourse affects the reader, as well as about the national identity of the Italian and English newspaper. In conclusion the author emphasizes that the influencing potential of discourse is realised through the expressiveness of linguistic means.

Keywords: publicistic discourse, journalism, discourse analysis, semantics, pragmatic approach, communicative and pragmatic aspect, emotive function, emotivity, Italian article, English article, emotive expressive means

\section{Введение}

Публицистический стиль, являясь одним из функциональных стилей речи, используется для написания статей, отчетов, интервью, очерков и т.д. на различные социальные и политические 
темы. Его основные функции - информационная и воздействующая, которые используются вместе, поскольку автор обращается к публицистическому стилю, когда перед ним стоит задача не только донести информацию до читателя, но тем или иным образом повлиять на него (Malyuga \& Orlova, 2017) . Данная задача осуществляется автором при помощи использования различных лингвистических средств, таких как многозначность слов, словообразовательные ресурсы (авторские неологизмы), эмоционально-экспрессивная лексика (наиболее часто используемые - эпитеты и метафоры), синтаксические средства выражения эмотивности (риторические вопросы и восклицания, повторы, эллипсис, инверсия, парцелляция, антитеза, градация и т.д.) (). Публицистический стиль позволяет убедить читателя в обоснованности выдвинутой инициативы автора и вызвать желаемую реакцию на сказанное при помощи логических рассуждений и эмоциональной напряженности высказывания, демонстрируя те особенности явления, которые можно наиболее эффективно использовать для достижения цели.

Для публицистического стиля характерны как черты научного стиля, то есть логика и последовательность изложения, так и образность и эмоциональность, присущие художественному стилю, поскольку он находится на стыке этих двух стилей.

Публицистический дискурс кажется монологом, но по своей природе он диалогичен. Автор текста стремится не столько проявить свои способности в области языковых навыков и теоретической лингвистики, сколько оказать необходимое воздействие на адресата, незаметно убедить его в чем-то выгодном для самого автора. Следовательно, используемые языковые средства должны успешно воздействовать на представителей всех слоев населения.

Шаховский В.И. придерживался мнения, что эмотивность текста формируется на всех уровнях языка и способствует созданию общей выразительности, которая реализует функцию влияния (Шаховский, 2009). Эмотивность, по его мнению, выступает как лингвистическая категория, означающая способность языковых единиц отражать субъективно индивидуальные переживания определенных эмоций человека.

В рамках данной статьи эмотивность трактуется как 
лингвистическая характеристика сочетания языковых средств, способных произвести эмоциональный эффект, то есть вызвать определенные эмоции у адресата.

Выразительность можно отнести к прагматическим категориям, «это сознательное воздействие на слушателя с точки зрения впечатляющей силы высказывания, выразительности, его эстетической характеристики» (Пиотровская, 1993). Таким образом, выразительность - категория, направленная на адресата, то есть она имеет прагматическое значение.

Эмотивность - это компонент выразительности, отражающий влияние текста на эмоциональную, неинтеллектуальную сферу человеческой психики. Она выступает средством выражения эмоций, чувств, аффектов и настроения адресата, передает его отношение к предметам и явлениям объективной реальности, а также влияет на чувства окружающих.

Шаховский В.И. пишет о взаимосвязи между эмотивной и воздействующей функциями: «Эмотивность является наиболее важным компонентом прагматики языка, поскольку наиболее ярко воплощает в себе ее воздействующую функцию» (Шаховский, 2009, с. 5).

\section{Материалы и методы исследования}

Материалом исследования являются статьи в электронном формате таких известных итальянских и английских газет, как La Repubblica, Corriere della Sera и La Stampa, the Guardian, the Telegraph.

Метод выбора статей обусловлен тем, что в работе было важно представить современную прессу, поэтому выборка статей производилась из изданий 2019-2020 гг., при этом выбранные темы в основном касаются влияния и формирования общественного мнения, поэтому используемый в статьях язык является подходящим для изучения явлений формирования речевого воздействия.

Изначально авторы планировали сосредоточиться только на монотипическом подходе, выбирая темы, посвященные экономике, политике или экологии. Однако при подготовке материала было обнаружено, что выбор статьей разных тематических групп позволяет увидеть то, как функция влияния используется в работе с общественным мнением. 
Таким образом, авторами были отобраны статьи преимущественно на следующие тематики: хроники, политика, наука, технологии.

Авторы использовали следующие методы лингвистических исследований:

- описательный метод, используемый при анализе и изучении форм, структур и процессов на всех уровнях языковой структуры: фонологии, морфологии, синтаксисе, лексике, семантике и прагматике;

- сопоставительный метод сосредоточен на функционировании лингвистической структуры. При использовании этого метода важно соотносить как некоторые элементы языка, так и целые области структуры;

- контекстологический анализ заключается в изучении языковой единицы в контексте. Только принимая во внимание биографический, социально-исторический, литературный, культурный и лингвистический контекст, мы можем полностью судить о содержании текста;

- метод количественного анализа, выявляющий вероятностные статистические данные, а также наиболее частотные, центральные элементы текста. Этот метод важен для определения стилистического признака текста, для изучения отличительных языковых особенностей, характерных тому или иному автору.

\section{Современные итальянские газеты}

Среди самых популярных итальянских газет необходимо выделить такие, как La Repubblica, Corriere della Sera и La Stampa.

Стоит отметить, что с момента зарождения журналистской профессии окончание Второй мировой войны стало деликатным и решающим историческим моментом для итальянской газеты. После устранения фашистской политики в стране необходимо было освободиться от той риторики, которая разрушала выразительность газетных статей, содержание которых касалось только пропаганды и подвергалось цензуре.

Другими словами, произошло то, что газеты перешли от одной проблемы к другой. Статьи были подготовлены в соответствии с правилами традиционной грамматики и совсем не были открыты для нововведений, более того, присутствовали сложные синтаксические конструкции и сложная терминология, которую 
нелегко расшифровать. Только газета Il Giorno попыталась выйти из этой логики, открывшись наиболее популярному стилю. Но это был единичный случай.

В середине 1970-х эта удушающая выразительность начала уходить со страниц газет после тридцати лет безмятежного господства. Изменения произошли с момента основания газеты La Repubblica в 1976 году Эудженио Скальфари, которая сообщала о новинках не только с точки зрения содержания, но также на политическом и лингвистическом уровне. Ему удалось создать модель, которая вышла за рамки назойливой газетной лексики, в пользу коммуникации, далекой от однообразия и неясности смысла. Это новое отношение не осталось в пределах $\mathrm{La}$ Repubblica, a расширилось, находя все больше и больше сообщников с итальянской точки зрения. Направление публицистического стиля в Италии стало смесью общих элементов повседневной речи с культурными и востребованными отсылками. Непосредственно в результатах исследования изложены и обоснованы примеры употребления разговорных фраз в статьях.

В основе изменения высказываний лежали причины иного характера, которые не могли быть связаны только с языком. Станет яснее, если мы обратимся к современному построению газеты La Repubblica: основное внимание уделяется политике по сравнению с новостями, и, помимо представления новостей, газета имеет тенденцию их комментировать. Можно судить о том, что это является прогрессивным шагом авторов, сумевших дать газете еще больше оригинальности и влияния на конкурентном рынке. Таким образом, именно общество, исторический и политический контекст повлияли на формирование языка газет.

В этом смешении балансов время было благоприятным для того, чтобы приветствовать даже языковые метаморфозы, и литературный итальянский язык больше не был тем единственным, чему нужно было следовать и чего нужно было преследовать любой ценой. Таким образом, письменная и устная речь слились в разновидность, которая была признана и обозначена как Italiano neostandard (неостандартный итальянский). Именно из-за этого явления в газетах стали появляться две пересекающиеся линии: открытость речи и желание восстановить письменность. С одной стороны, старые 
стилистические элементы, которые обрекали письмо на неестественное окаменение, отбрасываются, в результате чего в печати появляется более упрощенный синтаксис и лексикон, состоящий из разговорных фраз; с другой стороны, возникает намерение сопровождать публицистический дискурс формами, которые оглашаются в речи, мало контролируемыми конструкциями и прямой речью.

Остановимся подробнее на описании итальянских газет. Как было сказано ранее, La Repubblica была основана в 1976 году Эудженио Скальфари. Из источника с сайта La Repubblica, миссией газеты является создание информированной, активной публики, поощряемой к участию в общественной жизни благодаря лучшему и более глубокому пониманию событий, идей и культуры в Италии и в мире. С этой целью La Repubblica собирает, проверяет, производит и распространяет информацию и другое содержимое, которое служит общественным интересам и помогает поддерживать здоровую коллективную среду. У газеты есть ряд этических принципов, основанных на максимальной прозрачности и ответственности, которым придерживаются ее работники. Основа работы ее журналистов - независимость, отказ от конфликта интересов, внимание к самым спорным точкам зрения, соблюдение прав человека и Конституции Италии. La Repubblica ссылается на ценности европейского единства, это многонациональная международная газета.

La Stampa была основана в Турине 9 февраля 1867 года. Опираясь на 150-летнюю историю, La Stampa стремится интерпретировать ценности светской, беспристрастной и независимой газеты. Как сказал Арриго Леви, «благодаря широте информации газета способствует росту просвещенного и зрелого итальянского общества». Сохраняя свою историческую идентичность как газета, прочно укоренившаяся на Северо-Западе, но имеющая международный охват, La Stampa продвигает ценности европейской культуры, прозрачность и эффективность государственного управления, инновации с чувством ответственности за будущее поколение. Отношения между газетой и ее читателями основаны на доверии к публикациям. В газете четко разделены общие стандарты и ценности, руководящие принципы, касающиеся как журналистской работы, так и всех 
сотрудников газеты.

Corriere della Sera была основана в 1876 году и по традиции является ведущей национальной газетой. Благодаря своему авторитету она веками находится в центре национальной жизни, собирая и анализируя социальную, культурную, политическую и экономическую динамику. Благодаря простому и ясному стилю, эффективному, но умеренному языку и чистой и увлекательной графике, она становится все более современной, доступной и приятной для чтения, не теряя при этом серьезности и объективности. Ежедневно Corriere исчерпывающе удовлетворяет потребности читателя в информации и развлечениях: наряду с текущими событиями, политикой и новостными статьями, редактируемыми самыми известными именами в итальянской и международной журналистике; в ней также размещаются статьи о культуре, развлечениях и досуге.

Теоретические основания

По мере того, как публицистический дискурс и общество меняются, эмоции становятся гораздо более важной динамикой в том, как создаются и потребляются новости. Акцентирование внимания на эмоциях как на ключевом элементе переопределяет классическую идею журналистской объективности - на самом деле это меняет саму идею новостей. Это важно, поскольку публицистический дискурс играет все более ключевую роль в нашей жизни, так как информация, сведения и социальные сети становятся все более повсеместными и авторитетными. Ежедневный поток новостей в Интернете в сочетании с традиционными СМИ стал больше, чем когда-либо прежде. Потребители новостей имеют более широкий доступ к большему количеству журналистских материалов, чем прежде (Russell, 2011).

В настоящее время существует три фактора, побуждающих журналистов использовать эмоции в качестве инструмента. Первый фактор - экономический, поскольку конкуренция в сфере журналистики огромна. Как пишет Крис Петерс в своей работе, новости всегда были эмоциональными - разница сегодня заключается в растущем разнообразии эмоциональных стилей, возросшей приемлемости участия журналистов и в том, что попытки вовлечь аудиторию стали более явными (Peters, 2011). 
Второй фактор заключается в технологии. Существуют четкие доказательства того, что использование эмотивных средств помогает привлечь внимание читателей и продлить взаимодействие с ними. Источник с эмоционально захватывающими изображениями / карикатурами привлекает больше внимания. Текст, написанный на разговорном языке, как правило, увеличивает реакцию у потребителя информации. Следует отметить, что информация все чаще распространяется не через газетные киоски, а посредством социальных сетей. На журналистов возложена ответственность не только за презентацию и представление актуальной информации, но и за публикацию и популяризацию своей работы в сетях. Очень важно убедить людей распространять информацию, а эмоциональное воздействие имеет решающее значение для того, чтобы это произошло.

В-третьих, речь идет о лучшем понимании поведения людей, а также о культурологии и нейропсихологии, стоящих за этим. Понимание того, как люди относятся к новостям как на личном, так и на общественном уровне, жизненно важно для любого, кто хочет привлечь их к тому или иному источнику информации.

С теоретической точки зрения дискурс представляет собой сложное образование, отличающееся рядом элементов. С практической точки зрения дискурс и дискурс-анализ могут предоставить огромное количество лингвистической и экстралингвистической информации, которая может быть использована в различных исследованиях (социология, коммуникативные исследования, психология, экономика и т.д.).

Остановимся на слове «публицистический», чтобы подчеркнуть его современный смысл. Согласно В. Н. Левиной и С. В. Гуськовой, «понятие публицистического текста является синонимом концепции публицистического текста в современной научной парадигме. Существует определенный набор лингвистических критериев, по которым можно определить оригинальность любого текста, в том числе публицистического» (Левина, Гуськова, 2016, http). Фактически критерии развивают идею дискурса как особого текста, который является частью конкретной ситуации, происходящей в данном классе / обществе / культуре.

Понятие публицистического дискурса особенно интересно, 
когда мы анализируем его с точки зрения различных культур. Итальянская культура имеет очень давние и богатые традиции публицистического дискурса, риторика дискурса менялась с течением времени.

Коммуникативные особенности дискурса довольно широки, и они исходят от понятия общения как речевого акта производства текстовой информации. В зависимости от коммуникативной единицы дискурс может различаться и иметь определенные особенности.

Прагматические особенности дискурса можно описать как возможность применять дискурс в реальной жизни, поэтому он должен иметь все необходимые качества, чтобы быть полезным и, таким образом, соотноситься с реальностью и обществом. Лингвист Кобозева И.М. описала прагматический подход как прямое исследование условий речевого общения, поскольку они отражены в языковых выражениях.

Прагматический аспект играет очень важную роль и тесно связан с лингвистическим аспектом формирования текста: единицы текста составляются особым образом, от фонетического и фонологического до лексического уровней, чтобы привлечь аудиторию и поддерживать ее интерес к предмету. Более того, текст должен выполнять очень специфическую роль: недостаточно произвести впечатление, он должен предоставлять медиаинформацию, создавать конкретное видение обсуждаемого предмета, другими словами, иметь влияние на аудиторию. Таким образом, рассматривая единицы медиа-текста, мы можем сосредоточиться на двух аспектах, таких как «аспект привлечения внимания» и «аспект убеждения», которые оба очень важны в анализе данной работы.

\section{Результаты и обсуждение}

Эмотивный язык с точки зрения аргументации - это такой язык, вызывающий определенные эмоции у собеседника (у читателя, если речь идет о бумажном источнике), приводящие его к определенным заключениям. Метафоры или эвфемизмы используются для того, чтобы скрыть определенные понятия. Эвфемизмы в таких случаях принимают точное условное значение. Однако они также могут быть использованы и для сокрытия некоторых аспектов реальности, побуждая собеседника 
сделать вывод, основанный только на частичном представлении ситуации.

Открытость речи, внимание к реализму для достижения объективности, являются важными и центральными в итальянском публицистическом дискурсе. В семидесятые годы появление выразительности в итальянском публицистическом дискурсе принесло с собой прямую речь, которая заняла все более важные части текста. Факт включения прямой речи в текст ограничивает роль писателя, или, по крайней мере, только внешне. Таким образом теряются синтез и переформулирование новостей, а вместе с ними и специфика традиционного публицистического дискурса. От чрезмерного скопления и плохой читаемости, из-за нераспространенной лексики статей начала двадцатого века сегодня мы движемся к противоположному направлению, которое разбавляет и фрагментирует содержание статей сериями вопросов и ответов. Краткость изложения и упрощение текста произвели революцию в выразительности публицистического стиля, изменив традиционные логико-синтаксические связи.

Типов прямой речи, которые можно встретить в газетах, существует два - интервью и цитата. Не будем углубляться в первый тип, однако про цитирование скажем, что это самый распространенный прием в новостных статьях. С помощью цитаты создается впечатление спора, описания и рассказа о каком-то событии, она вводится в косвенную речь, перемежаясь с ней, граница между ними почти размывается. Следующий пример из итальянской газеты демонстрирует это:

«... Marinella si è poi scusato. «La persona ha insistito, gli abbiamo detto che vendiamo online ma poi abbiamo accettato che venisse - si è difeso, cercando di spiegare e giustificare quanto accaduto...»

«...Потом Маринелла извинилась: «Человек настоял, мы сказали ему, что продаем онлайн, но потом согласились, чтобы он пришел - он защищался, пытаясь объяснить и оправдать то, что произошло...»

Читатель должен очень внимательно относиться к непрерывным переходам от цитат к косвенной речи, так как есть риск потери нити повествования. Это также происходит из-за отсутствия передачи сигналов прямой речи, так как обычно глаголы, демонстрирующие это, отсутствуют (такие как сказать, 
добавить, спросить, указать, пояснить и т.д.), а стоят только кавычки. Следующий пример это демонстрирует:

«...«La mia passione per l'astronomia nasce a 22 anni mentre frequentavo la facoltà di Giurisprudenza». Paolo Zampolini ora di anni ne ha 33 e fa l'avvocato, vive a Viterbo e insieme a cinque amici ha fondato il Gruppo astrofili Galileo Galilei a Tarquinia...»

«...«Моя страсть к астрономии родилась в 22 года, когда я учился на юридическом факультете». Паоло Замполини сейчас 33 года, он работает юристом, живет в Витербо и вместе с пятью друзьями основал любительскую группу астрономов Galileo Galilei в Тарквинии...»

Писатели могут сократить цитату или дополнить ее своим мнением, представить и освятить ее в наиболее благоприятном для них положении. Таким образом, прямая речь является одним из эффективных способов воздействия на читателя.

Далее приведены примеры прямой речи из газеты The Guardian:

"...The driver of our car, a white woman, looked at the lone black man surrounded by police officers with their guns drawn and said: "It's good they've got so many on him. You never know what they'll do."”

«...Водитель нашей машины, белая женщина, посмотрела на чернокожего мужчину, окруженного сотрудниками полищии $c$ оружием, и сказала: "Хорошо, что у них так много оружия. Никогда не знаешь, что сделают эти чернокожие."”

Следующий пример:

«...A party spokesman said: "All reportable donations to the Conservative party are correctly declared to the Electoral Commission, published by them and comply fully with the law..."”

«...Пресс-секретарь партии сказал: "Все отчитываемые пожертвования в консервативную партию правильно объявлены в избирательной комиссии, опубликованной ею и полностью соответствуют закону..."”

Существует два ведущих способа использования эмотивных средств: слова могут использоваться для возбуждения эмоций, посредством представления ситуации, отличной от реальности; или термины, обычно связанные с отрицательным или положительным представлением ситуации, могут употребляться для изменения оценки уже известной ситуации. Это различие 
имеет решающее значение для понимания связи между значением слова и эмоциями, которые оно вызывает.

Лексические средства находятся на главенствующей позиции среди эмотивных средств языка. На данный момент выделяется следующая тенденция в изучении лексических средств: а) исследование отдельных эмотивных лексем; б) изучение лексикосемантических групп эмотивной лексики; в) исследование синонимов / антонимов, относящихся к эмотивным средствам; г) исследование роли метафоры в смысловой репрезентации эмоций.

Кажется, что разговорные выражения представляют собой наиболее существенный лексический пласт публицистического дискурса, в соответствии с тенденцией употреблять простой язык, который используется в повседневной жизни читателей, хотя и с должными оговорками. В большом количестве разговорных фраз Бономи признает языковой выбор, который частично является преднамеренным, а частично - признаком пренебрежения при составлении текстов. Однако следует иметь в виду, что выбор наиболее употребительного слова вместо более сложных его синонимов может соответствовать поиску определенной выразительности, из чего можно заключить, что разговорные фразы - потенциально эмотивные. Их можно назвать «ключевыми» компонентами, «фундаментальными частями», находящимися в рамках суждения, а также всего текста (Bonomi, 2016).

Было проанализировано наличие разговорной лексики в статьях итальянских газет. Получился следующий набор слов, который мы выбрали для нашего исследования:

- именные и словесные фразы, наделенные большой выразительностью, как vederci chiaro / ясно видеть, canta vittoria / поет победу, picchia/picchiano duro / бьет/бьют сильно, montagna di quattrini / гора денег;

- smetterla / прекратить;

- stavolta / на этот раз;

- infatti / на самом деле

- strombazza / шумно рекламирует;

- perdere la faccia / потерять лицо (потерять честь).

Единственное уточнение, которое мы можем сделать, это то, что есть более распространенные выражения и без определенной 
функции, такие как smetterla, stavolta, vederci chiaro, которые отличаются от других разговорных фраз, принадлежащих к определенным областям, таким как girare / переключать (компьютерную программу) в отношении того, как это работает.

В следующем примере, взятом из газеты La Stampa, разберем разговорную фразу perdere la faccia.

"...Una maniera per non "perdere la faccia», letteralmente, in tempi di pandemia ...»

«...Способ не «потерять лицо» буквально во время пандемии ...»

«Потерять лицо (потерять честь)» - типичное словосочетание в разговорной речи итальянского языка, используемое для описания ситуации, в которой человек теряет репутацию, престиж или достоинство. То есть, выражение «потерять лицо» означает, что человек больше не имеет смелости показать, какой он есть, из-за обстоятельств, в которых была потеряна его честь. Однако в данной ситуации фраза теряет свой первоначальный смысл; автор статьи намеренно использует фразу «потерять лицо», чтобы рассказать читателю про изобретение новой маски во время пандемии, изображающей лицо носящего ее. Таким образом, такая неоднозначная фраза привлекает внимание читателя и заинтересовывает его в прочтении статьи.

В данном примере присутствует слово, используемое в разговорной речи, infatti / на самом деле.

"...Il fedele e affezionato compratore infatti è stato sanzionato perché si trovava al di fuori dal proprio Comune di residenza...»

«...На верного и преданного покупателя на самом деле были наложены санкиии, потому что он находился за пределами своего муниципального проживания...»

Из этой же статьи La Stampa мы видим еще одно разговорное слово stavolta / на этот раз.

«...Abbiamo sbagliato, io cerco sempre di essere corretto ma stavolta abbiamo avuto una debolezza ...»

«...Мы ошиблись, я всегда стараюсь поступать правильно, но на этот раз на нас была минутная слабость...»

Stavolta - наречие, которое встречается в письменной форме с 1950 года и употребляется в основном в разговорной речи, происходит от фразы «questa volta», которая подверглась аферезе 
(фонетическое явление, при котором происходит выпадение начального звука в слове), и два элемента слились в один. Такой же процесс произошел и с другими наречиями времени, такими как «stamattina / сегодня утром» и «stanotte / сегодня вечером», широкое распространение и использование которых, в особенности в письменной форме, не позволяет задуматься, что они являются разговорными. Неудивительно, что у слова stavolta / на этот раз такое большое количество случаев употребления, которые уже проникли как в устную, так и в письменную речь.

Мы не можем отрицать того, что, исключая список выбранных слов, в газетах широко распространена блестящая выразительность и использование только стандартной лексики, более или менее подчеркнутой в соответствии с редакционными направлениями газет. Отходя от нашего исследования, следует сделать некоторые пояснения: выразительность языка превалирует в газетах во всех ее сферах, проявляя себя в качестве инструмента для сближения автора с читателем, а также в соответствии с тенденцией к упрощению информации и желанием привлечь читателя к покупке газет в период распространения информации по большей части в социальных сетях. С другой стороны, часто встречаются нецензурные выражения в газетах, вдохновленных ярко выраженной и радикальной политической линией, например, «Fatto Quotidiano» или «Libero» нередко используют экспрессивный и оскорбительный язык (Bonomi, 2016). Хотя мы не можем сделать оценочное суждение, с другой стороны, следует отметить, что желание произвести впечатление на отличительную модель в письменной форме часто приводит к созданию текста, в котором игнорируется информативный аспект, а все усилия автора сосредоточены на попытке «ослепить читателя». Однако из нашего анализа выявляется довольно ограниченный тип такой разновидности.

В ходе нашего исследования также были проанализированы английские статьи на наличие разговорной лексики и проведен сравнительный анализ.

Далее пример из газеты The Telegraph:

«...Feels pretty mисh like a Cold War to me...» «...По ошущениям для меня очень даже как холодная война..»

Фраза pretty much является неофициальной, однако мы видим 
ее в статье на политическую тематику.

Далее пример неформального слова freak:

«...This was not a freak policy of Dave and George...» «... Эma политика Дейва и Джорджа не была странной...»

В ходе сравнения итальянского и английского публицистического дискурса было выяснено, в обоих языках используются разговорные фразы и выражения.

Зачастую в газетах встречаются политические и журналистские термины, благодаря которым у читателя складывается определенное впечатление и умозаключение (Sokolova, 2020). Представители той или иной культуры как правило понимают значения большинства политических и социально-политических терминов.

Мы также подчеркиваем потенциальную роль коммуникативной компетенции и мотивов использования политического выражения в публицистическом дискурсе. Коммуникативная компетентность определяется как воспринимаемая эффективность и целесообразность, которые, по мнению людей, связаны с необходимостью достижения целей межличностного общения (Canary, Spitzberg, 1987). В контексте цифровых медиа восприятие компетенции может отличаться по мере изменения коммуникативных практик людей (Spitzberg, 2006).

Мы понимаем выражение политических взглядов как сообщение, которое представляет определенное мнение о текущих событиях или политических процессах, или распространяет информацию, имеющую отношение к интерпретации этих событий или процессов. Политическое выражение - это политическое поведение, с которым также связаны факторы и динамика межличностного общения. В этом смысле представления людей о том, насколько они компетентны в своих межличностных коммуникационных взаимодействиях также имеют значение, при изучении выражения мнений прослеживаются в публицистических статьях.

По направленности эмотивности общественно-политическую лексику можно разделить на три группы:

1) имеющую позитивную оценку;

2) имеющую отрицательную оценку; 
3) имеющую нейтральную оценку.

В следующем отрывке из статьи можно увидеть журналистский термин spaccarsi.

«...Ora su Mario Draghi $i$ gruppi pentastellati rischiano di spaccarsi...»

«...Tеперь на Марио Драги группь 5 звезд (итальянская политическая партия «Движение пяти звезд») находятся под угрозой разделения...»

Изначально термин имеет значение что-то сломать, действуя намеренно и используя физическую силу, однако в последнее время имеет также значение журналистское и политическое, а именно создать внутри партии, движения или собрания разделение, восприимчивое к серьезным последствиям. Таким образом, используя негативооценочное слово, автор вызывает определенные эмоции у читателя.

Ниже приведен отрывок из статьи, взятой из газеты La Stampa (24 февраля 2020 г.), где было рассмотрено такое выразительное средство синтаксиса как риторический вопрос.

«Ma Quanta gente dovete sfamare con tutto questo cibo?...»

«Но сколько людей нужно накормить всей этой едой?...» (La Stampa, Cronicles)

Риторические фигуры являются имитацией диалогических отношений в монологической речи автора, представляющей собой обмен репликами с аудиторией. Одна из особенностей риторических фигур - использование вопросительной и восклицательной интонации, за счет чего высказывание приобретает эмоциональную окраску.

С помощью вопросительной конструкции кажется, что автор создает эффект диалога, но на самом деле он снижает категоричность побудительного высказывания. Коммуникативное намерение можно определить в желании автора убедить адресата в том, что не было необходимости покупать товары в огромных количествах и создавать ажиотаж в супермаркетах.

Следующий фрагмент статьи взят из газеты Corriere della Sera, где также продемонстрирован риторический вопрос. Статья посвящена эволюционному развитию человека, отличиям в стадиях развития человека разумного от млекопитающих, в особенности в сравнении с шимпанзе. 
"...ma se guardiamo la testa rotonda, gli occhioni e la faccia piatta di un cucciolo di scimpanzé ci sembrerà umano in un modo quasi inquietante. Siamo scimmie bambine, dunque fragili. Ma come ̀̀ possibile? Non ha senso, dovremmo già essere estinti...»

«...но, если мы посмотрим на круглую голову, большие глаза и плоское лицо детеныша иимпанзе, оно почти жутким образом будет казаться человеческим. $\mathrm{Mbl}$ - обезьяны детеныши, поэтому мы уязвимы. Как это возможно? В этом нет смысла, тогда мы должны были бы вымереть...»

Автор статьи употребляет риторический вопрос для того, чтобы направить внимание читателя на ранее сказанную фразу, подчеркнуть ее значимость и с помощью вопроса задержать внимание читателя на проблеме. Кроме того, мы встречаем стилистически окрашенную лексику в данном отрывке, in un modo quasi inquietante / почти жутким образом, что делает акцент на усилении схожести именно ребенка шимпанзе с человеком, а также внимание читателя сосредотачивается на парадоксальности того, что люди до сих пор живы, несмотря на то что лицо человека больше схоже с лицом детеныша обезьяны, чем взрослой особи.

Нередко автор начинает статью именно с риторического вопроса, чтобы сильнее приковать читателя к той или иной проблеме. При использовании вопроса в начале статьи, у автора больше шансов на то, что читатель продолжит ее читать.

Далее начало статьи из газеты the Telegraph:

"What is so funny about patriotism?...»

"Что такого смешного в патриотизме? ...»

Следующий пример взят из газеты the Guardian:

"...Some may want to call the events of June 2020 a "racial reckoning", but in a country in which there was a civil war and a civil rights movement 100 years apart, at some point it would be useful to ask how long a reckoning need take. When, if ever, will we have reckoned?»

«...Некоторые назовут события в июне 2020 года «расовой расплатой», однако в стране, в которой была гражданская война и движение за гражданские права 100 лет назад, было бы полезно спросить в какой-то момент, как долго потребуется расплата. Когда, если вообще когда-то, мы рассчитаемся?»

Таким образом, употребление риторического вопроса в статье 
усиливает эмоциональность, выразительность и яркость речи, возбуждает у читателя интерес к тому или иному явлению, задерживает внимание читателя.

Обращаясь вновь к итальянским газетам, следует упомянуть такое достаточно частое явление, как заимствования. На данный момент в итальянских газетах наблюдается тенденция использования писателями английских терминов, фраз и слов для усиления значения написанного или сказанного. С психологической точки зрения использование заимствований, как кажется, придает итальянскому языку авторитет и статус. Именно английский язык выступает в качестве предпочитаемого языкадонора итальянцев и показывает то, что современные писатели готовы к повсеместному заимствованию иностранных слов в свой родной.

Эта колоритная и выразительная техника называется переключением кода (switching of codes). Переход с одного языка на другой всегда можно отметить на границах предложений, а в особых условиях языкового контакта билингвы не могут соотнести все предложение (иногда фразу) с точки зрения грамматики к тому или иному языку.

Далее дан отрывок статьи из газеты Corriere Della Sera / Coronovirus News из раздела Новости.

«...A essere pericolosi sono dunque più che altro "superspreading events», ovvero eventi di supercontagio. Sebbene qualsiasi persona infetta possa diffondere il virus ci sono circostanze in cui i contagi possono diventare incontrollabili...»

«...Следовательно, быть опасным - это больше, чем что-либо еще, "сверхраспространение событий» или события сверхзаражения. Хотя любой инфицированный человек может распространить вирус, существуют обстоятельства, при которых инфекиии могут стать неконтролируемыми...»

Так, можно сделать вывод, что современные авторы регулярно обращаются к иностранным словам при написании статей для ведущих итальянских газет. Необходимо упомянуть, что авторы прибегают не только к иностранным словам из английского, но и из других языков. С точки зрения выражения категории эмотивности прежде всего именно заимствования употребляются для придания достоверности повествуемого, для передачи 
образности и выразительности фразы.

\section{Выводы}

В результате проведенного исследования можно заключить, что эмотивные средства в итальянском и английском публицистическом дискурсе используются для воздействия на читателя, для передачи отношения автора к обсуждаемой проблеме. Анализ материала показал, что самая выразительная риторическая фигура $\mathrm{c}$ наибольшей частотой упоминаний в итальянском, а также английском публицистическом дискурсе это риторический вопрос. Он подчеркивает эмоциональную функцию и представляет реакцию автора на сообщение, содержащееся в предыдущих отрывках текста. Риторический вопрос направляет внимание читателя на ранее сказанную фразу, подчеркивает еe значимость; с помощью вопроса автор задерживает внимание читателя на описываемой проблеме.

Анализ использования в публикациях цитат показал, что цитирование - наиболее распространенное явление в английских статьях, нежели в итальянских, в особенности широко используется в разделах «бизнес» и «политика».

Достаточно заметной тенденцией в итальянских статьях является использование заимствований, в частности английских терминов, фраз и слов, которые вводятся для усиления значения написанного. С психологической точки зрения благодаря заимствованиям итальянский язык приобретает авторитет и статус. Как показал анализ, в английских статьях используется минимальное количество заимствований или не используется вообще, что обусловливается тем, что английский - язык мирового масштаба, на котором говорят во многих странах.

Кроме того, была выявлена большая частота употреблений разговорной лексики в статьях. Выбор наиболее употребительного слова вместо более сложного аналога может соответствовать поиску определенной выразительности, из чего можно сделать вывод, что разговорные фразы - потенциально эмотивные. В ходе сравнения итальянского и английского публицистического дискурса было выявлено регулярное использование разговорных фраз и выражений в обоих исследуемых языках.

Таким образом, можно прийти к заключению, что как в современной итальянской прессе, так и в английской функция 
передачи информации и функция влияния являются главными, порой невозможно определить, какая из них превалирует. Когда автор изобретателен и прибегает к творческому использованию правильных лексических средств, его публикации способны оказать особое влияние на читателя.

\section{Литература}

1. Иванова И. П. Стилевые характеристики публицистического дискурса // Ученые записки Тамбовского отделения РоСМУ, 2014. Режим доступа: https://cyberleninka.ru/article/n/stilevyeharakteristiki-publitsisticheskogo-diskursa (дата обращения 16.01.2021)

2. Комлева Е. В. Апеллятивность в языке и речи (на материале современного немецкого языка) // Вестник ЛГУ им. А.С. Пушкина, 2008. №5 (19). С. 152-164.

3. Малюга Е.Н., Попова К.В. Лингвопрагматика речевых стратегий в социальной рекламе // Вестник Московского государственного областного университета (электронный журнал), 2018. №4. С. 231-241. Режим доступа: www.evestnikmgou.ru. (дата обращения 16.01.2021)

4. Малюга Е.Н. Функции юмора в англоязычном экономическом дискурсе // Вестник Московского университета. Серия 9. Филология. 2020. № 6. С. 31-43.

5. Никонова Е.А. Специфика реализации воздействующей и манипуляторной функции в политическом англоязычном эссе // Вестник Томского государственного педагогического университетаю 2018. №7 (196). С. 9-14.

6. Пиотровская Л. А. Эмотивность как языковая категория // Вестн. С.-Петербургского ун-та. Сер. история языкознания, 1993. Вып. 2. №9. С. 41-47.

7. Санжеева Л.Ц., Очиров Т.Е. Манипулятивная функция политических реалий в публицистическом дискурсе // Вестник БГУ. Язык, литература, культура, 2017. №2. Режим доступа: https://cyberleninka.ru/article/n/manipulyativnayafunktsiya-politicheskih-realiy-v-publitsisticheskom-diskurse (дата обращения 16.01.2021) 
8. Солганик Г.Я. О структуре и важнейших параметрах публицистической речи (языка СМИ) // Язык современной публицистики: сб. ст. М.: Флинта: Наука, 2007. С. 13-31.

9. Урина Н. В. Очерки истории итальянской журналистики. М.: Фак. журн. МГУ, 2018. Режим доступа: http://www.journ.msu.ru/upload/iblock/17c/17c8361580a8aa9a2c5 9b4ff89c8d5e0.pdf (дата обращения 16.01.2021)

10. Черданцева Т.З. Очерки по лексикологии итальянского языка. Москва: ЛКИ, 2007.

11. Шаховский В.И. Категоризация эмоций в лексикосемантической системе языка. М.: Либроком, 2009.

12. Шаховский В.И. Типы языковых значений эмотивной лексики // Вопросы языкознания, 1994. №1. С. 20-26.

13. Bonomi I., L'italiano giornalistico. Dall'inizio del '900 ai quotidiani online, Firenze, Franco Cesati Editore, 2002.

14. Bonomi I., Maraschio N., L'Italiano. Conoscere e usare una lingua formidabile. Giornali, radio e tv: la lingua dei media, Roma, Gruppo Editoriale L'Espresso, 2016.

15. Canary D.J., Spitzberg B.H. Appropriateness and effectiveness perceptions of conflict strategies. Human Communication Research, 1987. №14. Pp. 93-120.

16. Cortelazzo M. L'Italiano giornalistico. Università degli Studi di Padova, Padova, 2016. Режим доступа: http://tesi.cab.unipd.it/57096/1/Giulia_De_Blasi_2017.pdf (дата обращения 16.01.2021)

17. Levina V.N., Guskova S.V. Publicistic Text in Modern Media Discourse and its Impact on the Audience // Indian Journal of Science and Technology, 2016. Vol. 9 (44). Режим доступа: www.indjst.org (дата обращения 16.01.2021)

18. Malyuga E. N., Tomalin B. Communicative strategies and tactics of speech manipulation in intercultural business discourse. Training, Language and Culture, 2017. - №1. - Pp. 28-48. Retrieved from https://rudn.tlcjournal.org/archive/1(1)/1(1)-02.pdf (дата обращения 16.01.2021)

19. Malyuga E.N., Orlova S.N. Linguistic pragmatics of intercultural professional and business communication. Springer, 2017. 
20. Peters C. Emotion aside or emotional side? Crafting an 'experience of involvement' in the news. Journalism. 2011. №12(3). Pp. 297-316. doi:10.1177/1464884910388224

21. Russell A. Networked: A contemporary history of news in transition. Cambridge, UK: Polity Press, 2011.

22. Sokolova A. G. Anglicisms and loanwords: The contribution of English exemplified by contemporary Italian tourist terminology // Training, Language and Cultureю 2020. №4(2). Pp.21-30. Doi: 10.22363/2521-442X-2020-4-2-21-30

23. Spitzberg B.H. Preliminary development of a model and measure of computer-mediated communication (CMC) competence. Journal of Computer-Mediated Communication, 2016. №11. Pp. 629-666.

\section{References}

Bonomi, I. (2002). L'italiano giornalistico. Dall'inizio del '900 ai quotidiani online [Journalistic Italian. From the early 1900s to online newspapers]. Firenze, Franco Cesati Editore.

Bonomi, I., \& Maraschio, N. (2016). L'Italiano. Conoscere e usare una lingua formidabile. Giornali, radio e tv: la lingua dei media, [Italian. Know and use a formidable language. Newspapers, radio and TV: the language of the media]. Rome, Gruppo Editoriale L'Espresso.

Canary, D.J., \& Spitzberg, B.H. (1987). Appropriateness and effectiveness perceptions of conflict strategies. Human Communication Research, 14, 93-120.

Cortelazzo, M. (2016). L'Italiano giornalistico [Journalistic Italian]. Università degli Studi di Padova, Padova. Retrieved from http://tesi.cab.unipd.it/57096/1/Giulia_De_Blasi_2017.pdf

Ivanova, I.P. (2014). Stilevye harakteristiki publicisticheskogo diskursa [Style peculiarities of publicity discourse]. Uchenye zapiski Tambovskogo otdeleniya RoSMU. Retrieved from https://cyberleninka.ru/article/n/stilevye-harakteristikipublitsisticheskogo-diskursa

Komleva, E.V. (2008). Apellyativnost' v yazyke i rechi (na materiale sovremennogo nemeckogo yazyka) [Appeal in Language and Speech (on the basis of a contemporary German language)]. Vestnik LGU im. A.S. Pushkina, 5 (19), 152-164. 
Levina, V.N., \& Guskova, S.V. (2016). Publicistic Text in Modern Media Discourse and its Impact on the Audience. Indian Journal of Science and Technology, 9 (44). Retrieved from: www.indjst.org (accessed 16.01.2021)

Malyuga, E.N., \& Popova, K.V. (2018). Lingvopragmatika rechevyh strategij $\mathrm{v}$ social'noj reklame [Linguo-pragmatics of speech strategies and tactics in social advertising]. Vestnik Moskovskogo gosudarstvennogo oblastnogo universiteta (elektronnyj zhurnal), 4, 231-241. Retrieved from www.evestnik-mgou.ru. (accessed 16.01.2021)

Malyuga, E.N. (2020). Funktsii iumora v angloiazychnom ekonomicheskom diskurse [Functions of humor in the Englishlanguage economic discourse]. Bulletin of Moscow University. Series 9. Philology, 6, 31-43.

Malyuga, E.N., \& Tomalin, B. (2017). Communicative strategies and tactics of speech manipulation in intercultural business discourse. Training language and culture, 1, 28-48. Retrieved from https://rudn.tlcjournal.org/archive/1(1)/1(1)-02.pdf (accessed 16.01.2021)

Malyuga, E.N., \& Orlova, S.N. (2017). Linguistic pragmatics of intercultural professional and business communication. Springer.

Nikonova, E. A. (2018). Specifika realizacii vozdejstvuyushchej i manipulyatornoj funkcii $\mathrm{v}$ politicheskom angloyazychnom esse [Specifics of the implementation of the influencing and manipulative function in the political English language essay]. Vestnik Tomskogo gosudarstvennogo pedagogicheskogo universiteta, 7 (196), 9-14.

Peters, C. (2011). Emotion aside or emotional side? Crafting an "experience of involvement" in the news. Journalism, 12(3), 297316.

Piotrovskaya, L. A. (1993). Emotivnost' kak yazykovaya kategoriya [Emotivity as a linguistic category]. Vestnik SanktPeterburgskogo universiteta. Seriya Istoriya yazykoznaniya №2, 9, $41-47$.

Russell, A. (2011). Networked: A contemporary history of news in transition. Cambridge, UK: Polity Press.

Sanzheeva, L.C., \& Ochirov, T.E. (2017). Manipulyativnaya funkciya politicheskih realij $\mathrm{v}$ publicisticheskom diskurse [Manipulative 
function of political realities in publicistic discourse]. Vestnik $B G U$. Yazyk, literatura, kul'tura, 2. Retrieved from https://cyberleninka.ru/article/n/manipulyativnaya-funktsiyapoliticheskih-realiy-v-publitsisticheskom-diskurse. (accessed 16.01.2021)

Sokolova, A.G. (2020). Anglicisms and loanwords: The contribution of English exemplified by contemporary Italian tourist terminology. Training, Language and Culture, 4(2), 21-30. Doi: 10.22363/2521-442X-2020-4-2-21-30

Solganik, G.Ya. (2007). O strukture $i$ vazhnejshih parametrah publicisticheskoj rechi (yazyka SMI) [The structure and the most important parameters of publicistic speech (media language)]. Yazyk sovremennoj publicistiki. M.: Flinta: Nauka.

Urina, N. V. (2018). Ocherki istorii ital'yanskoj zhurnalistiki [Essays on the history of Italian journalism]. M.: Fak. zhurn. MGU. Retrieved from http://www.journ.msu.ru/upload/iblock/17c/17c8361580a8aa9a2c5 9b4ff89c8d5e0.pdf (accessed 16.01.2021)

Cherdanceva, T. Z. (2007). Ocherki po leksikologii ital'yanskogo yazyka [Essays on the lexicology of the Italian language]. Moscow: LKI.

Shahovskij, V.I. (2009). Kategorizaciya emocij $v$ leksikosemanticheskoj sisteme yazyka [Categorization of emotions in the lexical-semantic system of the language]. M.: Librokom.

Shahovskij, V.I. (1994). Tipy yazykovyh znachenij emotivnoj leksiki [Types of linguistic meanings of emotive language]. Voprosy yazykoznaniya, 1, 20 - 26.

Spitzberg, B. H. (2006). Preliminary development of a model and measure of computer-mediated communication (CMC) competence. Journal of Computer-Mediated Communication, 11, 629-666.

Russell, A. (2011). Networked: A contemporary history of news in transition. Cambridge, UK: Polity Press. 